\title{
The SPARS Pandemic 2025-2028: A Futuristic Scenario to Facilitate Medical Countermeasure Communication
}

\author{
Emily K. Brunson ${ }^{1}$ (D) , Hannah Chandler ${ }^{2}(\mathbb{D})$, Gigi Kwik Gronvall $^{3} \mathbb{(}$, , \\ Sanjana Ravi ${ }^{3} \mathbb{D}$, Tara Kirk Sell ${ }^{3} \mathbb{D}$, Matthew P. Shearer ${ }^{\mathbb{D}}$, and \\ Monica Schoch-Spana ${ }^{3}$ (D)
}

1. Department of Anthropology, Texas State University, San Marcos, Texas, USA

2. Columbia University Mailman School of Public Health, New York, New York, USA

3. Johns Hopkins Center for Health Security and Department of Environmental Health and Engineering, Johns Hopkins Bloomberg School of Public Health, Baltimore, Maryland, USA

\begin{abstract}
Effective communication about medical countermeasures-including drugs, devices, and biologics - is often critical in emergency situations. Such communication, however, does not just happen. It must be planned and prepared for. One mechanism to develop communication strategies is through the use of prospective scenarios, which allow readers the opportunity to rehearse responses while also weighing the implications of their actions. This article describes the development of such a scenario: The SPARS Pandemic 2025-2028. Steps in this process included deciding on a time frame, identifying likely critical uncertainties, and then using this framework to construct a storyline covering both the response and recovery phases of a fictional emergency event. Lessons learned from the scenario development and how the scenario can be used to improve communication are also discussed.
\end{abstract}

KEYWORDS: prospective scenario, medical countermeasures, risk communication, public health emergency, crisis communication

Medical countermeasures (MCM) - including drugs, devices, and biologics (e.g., vaccines) - often play critical roles in curtailing the impacts of natural disease outbreaks as well as chemical,

CONTACTS Monica Schoch-Spana,PhD (D) · E-mail: mschoch@jhu.edu • Johns Hopkins Center for Health Security, 621 East Pratt Street, Suite 210, Baltimore, MD 21202 
biological, radiological, or nuclear (CBRN) incidents (Courtney \& Sadove, 2015). It is not uncommon for members of the public, however, to misuse or hesitate to take recommended MCM (Liu et al., 2017; Quinn et al., 2008; Steelfisher et al., 2011). New and unfamiliar technology, an accelerated regulatory approval process, or discordant expert views may heighten perceived risks of MCM, leading to public aversion to the countermeasure and/or diminished public trust in MCM regulators or recommenders (Belongia et al., 2005; Carlsen \& Glenton, 2016; Henrich \& Holmes, 2011). In other cases, strong feelings of vulnerability in an emergency situation may prompt persons to demand unnecessary MCM, protest their lack of access to MCM with limited availability, and/or use an excessive amount of prescribed MCM (Dart et al., 2015; Durigon \& Kosatsky, 2012; Whitcomb et al., 2015). In still other situations, certain social groups may have limited access to MCM because some institutions are still in the process of learning how culture, race, language, and citizenship status produce barriers to health information sharing (Lin et al., 2014; Uscher-Pines et al., 2011). To mitigate all of these issues and ensure proper and timely use of MCM, good communication is key.

From 2014 to 2016, the Center for Health Security undertook a research project to catalog MCM communication "dilemmas" (in the broad sense of a problem) in emergency situations and provide practical and strategic recommendations on how better to obtain desired population health outcomes through improved communication. The principal product was a casebook featuring recent health crises (e.g., 2014-2015 West Africa Ebola outbreak and 2011 Fukushima nuclear plant accident) that helped to illustrate the principles and conditions for effective MCM communication (Schoch-Spana et al., 2016).

Much of the practice-oriented literature relies upon real crises to illustrate successful (or failed) approaches to risk and crisis communication (e.g., Centers for Disease Control and Prevention [CDC], 2018; Ulmer et al., 2017). The project team similarly used past health emergencies to advance understanding of how communication enables appropriate public use of MCMs, because case studies have compelling benefits for learning: People reason effectively through analogy and not just abstract principles, 
contextualization makes broader principles meaningful and memorable, and cases promote reflective thinking and reinforce users' abilities to apply that knowledge in novel settings (Allchin, 2013; Epling et al., 2003).

Leveraging the same didactic qualities as retrospective cases (Varum \& Melo, 2010), the project team subsequently developed a fictionalized prospective scenario-The SPARS Pandemic 20252028 - to further prepare users for MCM-related risk and crisis communication dilemmas on the horizon. A scenario is an "analytically coherent" and "imaginatively engaging" story about a possible future state (Bishop et al., 2007) that spurs users to envision and exercise their role in shaping potential outcomes (Borjeson et al., 2006; Mahmoud et al., 2009; Wilkinson \& Eidinow, 2008). Outlined in this paper and available in full online (Schoch-Spana et al., 2017), the SPARS scenario is intended to help authorities better anticipate MCM emergency communication dilemmas, understand the larger contexts, practice effective responses, and develop acuity and agility for addressing unforeseen problems. The SPARS Pandemic 2025-2028 features MCM communication dilemmas both of the enduring and emerging kind-especially those in relation to evolving information and communication technologies (ICT).

\section{Benefits of Scenarios and Simulations in Preparing for Disasters and Epidemics}

The forward-looking SPARS scenario is a tool meant to prompt readers to imagine the dynamic and oftentimes conflicted circumstances in which MCM emergency communication takes place. By engaging readers with a rigorous, simulated health emergency the scenario provides opportunities for readers to mentally "rehearse" responses while also weighing the implications of their actions (Borjeson et al., 2006). Apart from testing out responses to foreseeable events, the scenario also provides readers opportunities to consider potential measures in today's environment that might avert comparable problems or classes of problems in the future; that is, consider how to create a preferred future (Bishop et al., 2007; Borjeson et al., 2006; Mahmoud et al., 2009; Wilkinson \& Eidinow, 2008). 
Producing coherent and imaginative narratives about the future to inform decision-making in the present is an approach to planning and risk management that businesses, think tanks, governments, and non-governmental organizations have embraced for a half century or more, and a wide range of aims, applications, and techniques have evolved (Bishop et al., 2007; Varum \& Melo, 2010; Wilkinson \& Eidinow, 2008). In the case of a lowprobability high-consequence event like a pandemic or CBRN incident in which MCM may be deployed, scenario development provides a way-absent an actual emergency-for stakeholders to characterize specific impacts (based on the accepted science), create a shared vision of the threat, weigh alternatives futures with or without risk-reducing interventions, and stimulate action (Earthquake Engineering Research Institute [EERI], 2019; Preuss \& Godfrey, 2006). Earthquake and bioterrorism scenarios, for instance, have played important roles in motivating creative thinking about the need for novel policies and programs and in mobilizing new constituencies around seismic risk reduction (National Research Council [NRC], 2011) and public health emergency preparedness (Hamilton \& Smith, 2006; O’Toole et al., 2002), respectively.

Scenarios that depict an unfolding crisis are valuable tools that can heighten awareness about complex hazards and also enable practical training for the management of disasters and epidemics through exercises (European Centre for Disease Prevention and Control [ECDC], 2014; Federal Emergency Management Agency [FEMA], 2019; World Health Organization [WHO], 2018). Discussion-based exercises (often called tabletop exercises) help participants, typically decision-makers, become more familiar with emergency plans and procedures, individual and organizational roles and responsibilities, and special challenges posed by a particular threat to public health and safety. By contrast, operation-based exercises (such as drills, functional exercises, and field exercises) attempt to incorporate, to a lesser or greater degree, the front-line personnel, equipment, and physical spaces expected to be in play during an actual emergency (FEMA, 2019; Skryabina et al., 2017). A majority of studies on the effectiveness of training in emergency risk communication, in particular, conclude 
that the impacts of tabletop exercises and simulation for training include enhanced awareness, readiness, and knowledge (Miller et al., 2017).

\section{Social Media Challenges/Opportunities for Health and MCM Communication}

Like the previously mentioned earthquake and bioterrorism scenarios, the SPARS scenario is meant to prepare risk and crisis communicators for future emergencies, and in particular the complex conditions that rapidly-evolving ICT, including social media, are now generating around medicine/public health generally and MCM specifically.

ICT use, including text, illustrations, photo, audio, videos, and diagrams communicated through blog posts, instant messages, video chats, and social network platforms, is now widespread and often used for health-related activities. Among members of the public, a 2010 survey by the Pew Research Center, for instance, showed that 8 in 10 internet users look online for health information, making it the third most popular online activity in the U.S. (Fox, 2011). Likewise, practitioners, public health officials, and other health experts are increasingly turning to ICT-which provides a means to reach the broadest possible population in the fastest, easiest, and least expensive manner (Hinton \& Hjorth, 2013) - for a variety of purposes. Clinician-to-patient and peerto-peer communication, investing individual patients in their own care, information exchanges among diverse healthcare and public health stakeholders, and detecting and managing disease outbreaks have been transformed through ITC (Charles-Smith et al., 2015; Grajales et al., 2014; Kreps \& Neuhauser, 2010; Rice \& Sara, 2018). While this situation may appear overwhelmingly positive, some aspects of ITC use and its popularity remain problematic.

First, ITC use has altered the dynamics between health experts and the patients and populations they serve (Hawn, 2009). Social media in particular has provided a mechanism for laypersons to readily share their health-related experiential knowledge with each other, thus dislodging the centrality of health professionals' authoritative knowledge in people's decision-making and behavior (Hawn, 2009; Househ et al., 2014). 
Second, ITC can, and is, used to spread false information. Wolfe and associates (2002), for example, found that $32 \%$ of antivaccine websites surveyed included pictures of "menacing needles" and $23 \%$ had pictures of children reported to have been harmed or killed by vaccines. As parents come across these images and their associated stories this can lead parents to place greater emphasis on personal and emotional experience rather than scientific evidence. Referred to as false consensus bias in the social psychology literature, parents may then hesitate to vaccinate or reject vaccines for their children altogether.

What is particularly challenging in regard to social media is that such images and negative stories tend to have a greater impact than facts and positive messages. In their research of vaccinationrelated YouTube videos, for example, Keelan and associates (2007) found that while the majority (48\%) of the 153 identified videos promoted vaccination and only $32 \%$ were negative toward vaccination, the most liked and viewed were the ones with negative content. The lowest rated and watched videos were provaccination public service announcements.

These positive and negative aspects of ITC, in turn, influence what practitioners and the broader public understand about MCM safety and efficacy, thus presenting new challenges and opportunities for crisis and risk communicators. Medication users, for example, are increasingly sharing personal knowledge and experience of drug benefits and risks via online disease support networks, patient and drug forums, and microblogging (Matsuda, 2017; Sloane et al., 2015). Through social media, these individuals can find both practical information and a sense of community, while drug safety professionals have a new, rich data source with which to mine for potential evidence of adverse events, supplementing uneven healthcare provider reports (Edwards \& Lindquist, 2011; Inch et al., 2012).

At the same time, great potential exists for the public to encounter misleading or dangerous information about pharmaceuticals, as non-expert consumers deliver their own drug product testimonials and illegal online pharmacies promote their services via social media (Tyrawski \& DeAndrea, 2015). Misinformation is proving especially challenging in connection with vaccines where 
social media users encounter disproportionate negative reporting and images, are more swayed by personal narratives about vaccination's adverse effects than the science, and tend to judge disparate ideas about vaccines as equally valid, regardless of expertise (Guidry et al., 2015; Kata, 2012; Poland et al., 2009; Witteman \& Zikmund-Fisher, 2012). Thus, in this current ITC-rich environment, good communication, and good training for effective communication, is critical.

\section{Methods}

To develop the SPARS scenario a project team with expertise in a variety of areas, including epidemiology, public health preparedness, risk communication, and the biological and social sciences, was assembled. Utilizing these diverse perspectives, the team used a combination of the inductive and deductive heuristics delineated by Ogilvy and Schwartz (2004) to develop the scenario premise (Figure 1). This process began with selecting the timeframe for the scenario-the years 2025-2028. These dates, which were 10-13 years in the future at the time, were chosen to provide a timeline that allowed the development of future possibilities, but was not so far in the future as to make the scenario become a work of science fiction. After the timeframe was established, the project team turned to the focal question: What emergency communication issues around MCM are most likely to exist 10 years from now?

To begin answering this question, the project team considered the key economic, environmental, political, social, and technological factors they felt were likely to emerge by 2025 . Factors considered by the project team included prominent ones such as technological advances like the proliferation of tools to access the internet, increased use of the internet for things like social media and telemedicine, greater political and social polarizations, changing demographics in the United States including an aging baby boomer population, and climate change and urbanization that could result in the (re)emergence of zoonotic diseases.

After careful discussion of each of these factors, which included consideration of existing literature and theoretical approaches, the team considered which factors seemed inevitable given present 


\section{FIGURE 1 The scenario generation process, adapted from Ogilvy and} Schwartz (2004).

\#1 - Identify focal issue and time frame

\#2 - Brainstorm a list of "key drivers"

\#3 - Sort "drivers" into "predetermined trends" and "critical uncertainties"

\#4 - Select top 2 "critical uncertainties" and build $2 \times 2$ scenario matrix

\#5 - Select 1 of the 4 futures and elaborate on a complete storyline

Deepen the plot through systems thinking

Tell a story with a beginning, middle, and end

Create characters

Employ standard plot lines

\# 6 - Refine the plot through an iterative process of reflection, research, and revision

\#7 - Explore the strategic implications of the scenario
Single out a key decision or a strategic uncertainty that has long-range consequences important to the organization

Consider notable forces shaping and influencing the focal issue: social, technological, economic, natural, political

Distinguish inevitable trends that will play out the same no matter what *versus* important trends whose impacts are unsure

Reduce each critical uncertainty to an axis with polar cases at each extremity; overlay the 2 axes and produce 4 futures to explore
Think of critical events, then delve into underlying patterns and structures that these events signal; use diagrams to see how forces interact

Capture time and causality dimensions; first this, then that; generate a series of headlines describing events over the course of the scenario

Personify the magnitude and direction of change by using real or iconic figues

Build on common narratives ("winners and losers" and "David and Goliath")

Return to initial focal issue to determine gaps, vulnerabilities, options facing the organization 
conditions and which were the most likely to impact the direction of the scenario. From this process, two critical uncertainties were identified: the extent of access to information technology, that the team felt was inevitable, and the degree of fragmentation among populations along social, political, religious, and cultural lines, which the team felt would lead to novel communication issues. The project team then used these uncertainties to construct a scenario matrix illustrating the four possible futures that could be shaped by these trends (Figure 2). After careful consideration, the team ultimately chose the "echo-chamber"-a world comprised of isolated and highly fragmented communities with widespread access to information technology-as the future in which the prospective scenario would take place.

\section{FIGURE 2 Final Scenario Framework: Four possible futures in which the} SPARS pandemic unfolds.

\begin{tabular}{|c|c|c|c|}
\hline \multicolumn{4}{|c|}{$\begin{array}{l}\text { Unbridled access and openness to information techn } \\
\text { media) }\end{array}$} \\
\hline \multirow{2}{*}{$\begin{array}{l}\text { Isolated } \\
\text { communities, } \\
\text { social } \\
\text { fragmentation }\end{array}$} & "Echo-chamber" & $\begin{array}{l}\text { "UN Security } \\
\text { Council" }\end{array}$ & \multirow{2}{*}{$\begin{array}{l}\text { Diverse but } \\
\text { integrated } \\
\text { communities, } \\
\text { "melting pot" }\end{array}$} \\
\hline & $\begin{array}{l}\text { "Solitary } \\
\text { Confinement" }\end{array}$ & "Shangri-La" & \\
\hline \multicolumn{4}{|c|}{ Erratic, unequal access to information technology (including social media) } \\
\hline \multicolumn{4}{|c|}{$\begin{array}{l}\text { "Echo-Chamber"-a technologically savvy, plugged in, but fragmented } \\
\text { society in which groups that hold diverse worldviews consume information } \\
\text { that continues to validate their own positions, allowing them to live in their } \\
\text { own mental bubble; government agencies and citizens alike have ready } \\
\text { access to all the latest informational tools. }\end{array}$} \\
\hline \multicolumn{4}{|c|}{$\begin{array}{l}\text { "Solitary Confinement" — a society (including general population and public } \\
\text { sector) with an uneven access to informational technology (due to lack } \\
\text { of net neutrality, uneven infrastructure) that isolates differently minded } \\
\text { communities. }\end{array}$} \\
\hline \multicolumn{4}{|c|}{$\begin{array}{l}\text { "UN Security Council"-a technologically savvy, plugged in society where } \\
\text { diversity reigns, but difference and tolerance are socially valued, and where } \\
\text { information flows freely across different groups. }\end{array}$} \\
\hline \multicolumn{4}{|c|}{$\begin{array}{l}\text { "Singapore" - a melting pot society, with peaceful co-existence of differently } \\
\text { minded groups, but uneven levels of access to information technology. }\end{array}$} \\
\hline
\end{tabular}


From this point, scenario-specific storylines were developed, drawing on the subject matter expertise of the project group, interviews with expert working group (EWG) members associated with the larger project, historical accounts of past MCM crises, contemporary media reports, and scholarly literature in sociology, emergency preparedness, health education, and risk communication. This process allowed the project team to identify expected and new communication dilemmas to include in the scenario. As one example of this, the project team considered how the internet and social media affect the social dynamics of health communication. Using the theory of false consensus bias and the findings on vaccination in social media (described previously in the literature review section), the project team identified specific communication dilemmas to include in the scenario. One of these involved responding to a particularly emotional video that was widely spread via social media and then maintained in the public view for months afterward by teenagers who enjoyed the shock value of the images. This specific case, titled "Going Viral," is presented later in this paper.

Once different dilemmas were identified, the team considered how the different storylines could reasonably fit together and what characters were necessary in order for these events to occur. An outline for the scenario was then constructed using newspaper and other social media headlines as markers for key events; in many instances, these remained in the scenario in order to introduce the different dilemmas. Finally, the entire storyline was written in draft form as if the SPARS outbreak had occurred in the recent past, allowing some outcomes and conclusions to be drawn within the scenario.

From this point, scenario development entailed a recursive process of continued research and analysis by the project team, review and feedback from EWG members (summer 2015), and two rounds of external review by authorities on risk communication and the MCM enterprise (four individuals in fall 2015, three individuals in summer 2017). Comprising the project EWG were risk and crisis communication scholars; MCM developers, producers, and regulators; practitioners in medicine, public health, 
and pharmacy science; and experienced public health emergency managers at all levels of government. Revisions were made after each review in order to increase the accuracy and usefulness of the material presented in the scenario.

The final product, referred to hereafter as the SPARS scenario, is not intended to be a crystal ball of things to come; rather, it is meant to serve as a plausible narrative that illustrates a broad range of serious and frequently encountered challenges in the realm of risk and crisis communication. To increase the usefulness of the scenario, each response- and recovery-phase dilemma is followed by food for thought questions that are meant to prompt readers, reading as individuals or in training groups, to consider how they might respond to similar situations or how they might prevent similar problems or classes of problems from occurring in the first place. Like the studies of scenario-driven exercises (Skryabina et al., 2017) show, including those featuring emergency risk communication (Miller et al., 2017), the SPARS scenario is intended to prepare users for mitigating public health emergencies and managing MCM communication dilemmas more effectively. In the following sections, we outline the scenario environment and how the fictional outbreak begins. We then provide excerpts of two dilemma sections as examples of the larger document.

\section{The SPARS Scenario: An Introduction}

\section{Scenario Environment}

The setting of SPARS is the world in 2025-2028. For this time period, the project team imagined a world that is simultaneously more connected and yet more divided. There is nearly universal access to wireless internet for even the poorest persons in the United States. Additionally, technological innovations and competition between technology companies have made an even wider range of information technology readily available to all. Despite the possibilities for these advancements to facilitate broad communication between individuals and communities, the project team also envisioned a future where many have chosen to self-restrict the sources they seek for information, often electing to interact 
only with those whom they agree with on significant issues. This trend increasingly isolates cliques from one another, making communication across and between these groups more difficult.

In relation to MCM communication more specifically, government agencies like the CDC have increasingly adopted social media technologies, including long-existing platforms such as Facebook, Snapchat, and Twitter, as well as emerging platforms like ZapQ-an interface that enables users to aggregate and archive media content from other platforms and communicate with cloud-based social groups based on common interests and current events. Federal and state public health organizations have also developed agency-specific applications and ramped up efforts to maintain and update agency websites.

Challenging this technological grip, however, are the diversity of new platforms and the speed with which social media communities evolve. Moreover, while technologically savvy and capable, these agencies still lag in terms of their "multilingual" skills, cultural competence, and ability to be present on all forms of social media. These agencies also face budget constraints, which complicates their efforts to improve public communications efficiency and effectiveness by increasing their presence in existing and emerging social media platforms.

\section{SPARS}

After much consideration of possible emergency situations that would require MCM use, the project team decided on setting the storyline around a novel coronavirus that caused a mild, flu-like disease in most instances, but pneumonia and/or hypoxia requiring hospitalization and extensive medical treatment in a small minority of cases. The project team named this fictional pathogen the St. Paul Acute Respiratory Syndrome Coronavirus, or SPARS for short, because in the scenario it is first identified in St. Paul, Minnesota.

Two features of this disease are important to note because they impact how the storyline of the scenario plays out, as well as some of the communication dilemmas that occur. First, the project team decided to make SPARS have an extended incubation period 
(7 to 10 days) but a short latent period ( 4 to 5 days). This complicates the scenario because infected persons in the story are capable of spreading the virus for up to 6 days before showing symptoms of the disease themselves. This feature of SPARS makes isolation procedures in the scenario, like urging people to stay home if they think they might be sick, less effective than what is typically expected for airborne pathogens and thus introduces novel dilemmas in the storyline. Second, the project team decided to make the morbidity and mortality from SPARS both significantly higher in children than adults, and among pregnant women and those with chronic respiratory conditions. This parallels disease characteristics associated with past disease outbreaks, including the $\mathrm{H}_{1} \mathrm{~N}_{1}$ pandemic, and allowed for some communication dilemmas from the past to be revisited under different future circumstances.

In all, the SPARS scenario provides 19 specific storylines, and an associated 23 communication dilemmas for readers to consider. An outline of the entire storyline is available in Table 1, and a list of the communication dilemmas provided in the scenario can be found in Table 2. The following sections provide excerpts of two dilemmas included in the scenario as well as their associated communication dilemmas and food for thought questions.

TABLE 1 Timeline of Events in the "SPARS Pandemic 2025-2028" Scenario

\begin{tabular}{|c|c|}
\hline \multicolumn{2}{|l|}{2025} \\
\hline October & $\begin{array}{l}\text { The first US deaths occurred due to SPARS. Initially, these } \\
\text { deaths were thought to have been caused by influenza. }\end{array}$ \\
\hline \multirow[t]{3}{*}{ November } & $\begin{array}{l}\text { Cases of SPARS were reported across Minnesota and in six } \\
\text { other states. }\end{array}$ \\
\hline & $\begin{array}{l}\text { Thanksgiving holiday travel and Black Friday shopping } \\
\text { facilitated spread of SPARS beyond the Midwest ( } 26 \text { states } \\
\text { and multiple other countries by mid-December). }\end{array}$ \\
\hline & $\begin{array}{l}\text { The WHO declared the SPARS pandemic to be a Public Health } \\
\text { Emergency of International Concern. }\end{array}$ \\
\hline December & $\begin{array}{l}\text { No treatment or vaccine for SPARS existed, but there was } \\
\text { some evidence that the antiviral Kalocivir could be effective } \\
\text { as a therapeutic. }\end{array}$ \\
\hline
\end{tabular}




\begin{tabular}{|c|c|}
\hline & $\begin{array}{l}\text { A proprietary vaccine developed and manufactured by a } \\
\text { multinational livestock conglomerate (GMI) was proposed } \\
\text { as a potential foundation for a human vaccine. The vaccine } \\
\text { was developed to combat an outbreak of a similar respiratory } \\
\text { coronavirus in hooved mammal populations in Southeast } \\
\text { Asia, but the vaccine had not been licensed by any regulatory } \\
\text { authority or tested in humans. There were concerns over } \\
\text { potential side effects. }\end{array}$ \\
\hline \multicolumn{2}{|l|}{2026} \\
\hline \multirow[t]{6}{*}{ January } & $\begin{array}{l}\text { The US government contracted CynBio to develop and } \\
\text { produce a human SPARS vaccine based on the GMI animal } \\
\text { vaccine. }\end{array}$ \\
\hline & $\begin{array}{l}\text { The HHS Secretary invoked the Public Readiness and } \\
\text { Emergency Preparedness Act (PREP Act) to provide liability } \\
\text { protection for the vaccine manufacturer and providers. } \\
\text { Congress authorized and appropriated emergency funds } \\
\text { under the PREP Act to provide compensation for potential } \\
\text { adverse side effects from the vaccine. }\end{array}$ \\
\hline & $\begin{array}{l}\text { Following reports of Kalocivir's limited success in treating } \\
\text { patients with severe SPARS infections, the FDA issued an } \\
\text { Emergency Use Authorization (EUA) for the antiviral. Kalocivir } \\
\text { had been evaluated as a therapeutic for SARS and MERS, } \\
\text { and several million doses were maintained in the SNS, which } \\
\text { could be deployed as necessary while production capacity } \\
\text { was established to meet demand. }\end{array}$ \\
\hline & $\begin{array}{l}\text { The FDA, CDC, and NIH provided seemingly conflicting } \\
\text { communications regarding the safety and efficacy of } \\
\text { Kalocivir. }\end{array}$ \\
\hline & $\begin{array}{l}\text { In the United States, public anxiety around SPARS resulted in } \\
\text { extensive use of Kalocivir, frequent self-reporting of SPARS } \\
\text { symptoms, and a surge in demand for medical care. }\end{array}$ \\
\hline & $\begin{array}{l}\text { By late January SPARS was detected in } 42 \text { countries and all US } \\
\text { states. }\end{array}$ \\
\hline \multirow[t]{2}{*}{ February } & $\begin{array}{l}\text { A lack of cultural competency in FDA and other } \\
\text { governmental communication became apparent among } \\
\text { various ethnic groups in the United States. }\end{array}$ \\
\hline & $\begin{array}{l}\text { A video of a 3-year-old vomiting and fainting after taking } \\
\text { a dose of Kalocivir was widely and rapidly spread via social } \\
\text { media, strengthening opposition to the EUA. }\end{array}$ \\
\hline
\end{tabular}




\begin{tabular}{|l}
\hline The UK Medicines and Healthcare Products Regulatory \\
Agency and the European Medicines Agency jointly \\
authorized the emergency use of a new antiviral, VMax, in the \\
United Kingdom and throughout the European Union. Some \\
Americans attempted to gain access to VMax online or by \\
traveling to Europe. \\
The CDC publicized an updated (and significantly lower) case \\
fatality rate in the United States; the perception of lesser risk \\
triggered a drop in public interest. \\
Production of Corovax, the SPARS vaccine produced by \\
CynBio, was well underway. \\
Federal agencies initiated a communications campaign using \\
well-known public figures with mixed results. Polls indicated \\
a 15-23\% increase in SPARS and Kalocivir knowledge \\
nationwide. Hip-hop icon BZee had success promoting \\
public health messaging with an online video clip, but he \\
lost credibility when he compared volunteers for Corovax \\
trials with "volunteers" from the Tuskegee syphilis study. \\
Similarly, former President Bennett provided a non-committal \\
response when asked if she would want Kalocivir for her new \\
grandson. \\
Public health agencies discovered that a relatively new social \\
media platform, UNEQL, was being used as a primary means \\
of communication in college-aged populations. \\
Corovax entered the final stage of its expedited review, and \\
production capacity was increased. Ten million doses were \\
expected to be available by July with fifty million more in \\
August. \\
The CDC Advisory Committee on Immunization Practice \\
(ACIP) announced vaccine priority groups. Healthcare \\
providers were not included as a priority, inciting protests by \\
doctors and nurses across the country. \\
In order to prioritize distribution of limited Corovax supply, \\
the federal government requested that states report \\
summary information for patient electronic health records \\
(EHRs) to estimate the number of individuals in high-risk \\
populations. This effort was met with resistance from the \\
public, who protested the federal government accessing their \\
private medical information.
\end{tabular}




\begin{tabular}{|ll|}
\hline July & A week prior to initiating the nationwide vaccination \\
program, damage to a power grid in the Pacific Northwest \\
resulted in a widespread power outage that lasted two \\
weeks. State and local public health agencies initiated \\
communications programs using posters and flyers to \\
promote the vaccination program in the absence of \\
electronic media. \\
Social media efforts across the country promoted the \\
vaccination campaign, and crowdsourced data helped to \\
increase efficiency in distributing the vaccine. \\
The Corovax vaccination program met resistance from several \\
groups: alternative medicine proponents, Muslims, African \\
Americans, and anti-vaccination activists. Initially operating \\
independently, these groups banded together via social \\
media to increase their influence. \\
Japan announced that it would not approve Corovax for \\
use in Japan in favor of developing and producing its own \\
vaccine. \\
College students predominantly on the East and West coasts \\
staged protests against the unequal global availability of \\
Corovax. Vaccination rates among these students were below \\
average for college students in other areas of the country. \\
The anti-anti-vaccine movement, formed in the wake of the \\
2015 measles outbreak in the United States, reignited their \\
efforts to combat the anti-vaccination super-group. The \\
FDA, CDC, and other federal agencies also redoubled their \\
communications efforts to promote the Corovax campaign. \\
An increasing number of post-SPARS pneumonia cases were \\
reported across the country. \\
The nationwide vaccination program was expanded beyond \\
the initial priority populations to include the rest of the \\
country. \\
Federal agencies initiated a vaccination communication \\
program involving targeted online advertisements.
\end{tabular}




\begin{tabular}{|c|c|}
\hline & $\begin{array}{l}\text { sufficient potency. Tests conducted in August } 2026 \text { provided } \\
\text { the basis for extending the expiration of these lots from } 2027 \\
\text { to } 2029 \text {. }\end{array}$ \\
\hline \multirow[t]{2}{*}{ March } & $\begin{array}{l}\text { Rumors spread via traditional and social media that the } \\
\text { government was dispensing expired antibiotics. }\end{array}$ \\
\hline & $\begin{array}{l}\text { Alyssa Karpowitz, a leader in the natural medicine movement, } \\
\text { sought medical care at an emergency department after } \\
\text { natural remedies failed to resolve her son's bacterial } \\
\text { pneumonia. After successful treatment with proper } \\
\text { antibiotics from the SNS supply, she touted the benefits of } \\
\text { "expired" antibiotics in her social media circles. }\end{array}$ \\
\hline April & $\begin{array}{l}\text { Crowd-sourced and independent epidemiology analysis of } \\
\text { Corovax side effects conflicted with official federal reports. } \\
\text { The independent analyses gained popularity in traditional } \\
\text { and social media due to visual presentation and interactive } \\
\text { content. Government attempts to respond with data and } \\
\text { press releases largely failed. }\end{array}$ \\
\hline May & $\begin{array}{l}\text { Reports of Corovax side effects began to gain traction. Several } \\
\text { parents of children who experienced neurological symptoms } \\
\text { after receiving the vaccination sued the federal government } \\
\text { and CynBio. The lawsuit was dropped when they learned of } \\
\text { compensation funds available through the PREP Act and the } \\
\text { National Vaccine Injury Compensation Trust Fund. }\end{array}$ \\
\hline \multirow[t]{3}{*}{ November } & $\begin{array}{l}\text { Initial reports of long-term side effects of the Corovax } \\
\text { vaccine emerged. These reports arose primarily from those } \\
\text { in the initial priority (high-risk) populations and were few } \\
\text { in number. With little available data and numerous pre- } \\
\text { existing conditions, initial studies were unable to identify a } \\
\text { statistically significant association with any long-term effects. } \\
\text { Claims for compensation were placed on indefinite hold until } \\
\text { further data could be gathered and analysis completed. }\end{array}$ \\
\hline & $\begin{array}{l}\text { In response to public demand for long-term side effect } \\
\text { compensation, the HHS Secretary invited Congress to } \\
\text { conduct an independent investigation of the federal } \\
\text { compensation process to alleviate concerns of impropriety. }\end{array}$ \\
\hline & $\begin{array}{l}\text { The public and media pressured Congress to increase the } \\
\text { funds authorized for compensation under the PREP Act. }\end{array}$ \\
\hline \multicolumn{2}{|l|}{2028} \\
\hline August & $\begin{array}{l}\text { The SPARS pandemic was officially declared to be over; } \\
\text { however, experts remain concerned about domestic animal } \\
\text { reservoirs and the potential for future outbreaks. }\end{array}$ \\
\hline
\end{tabular}




\section{TABLE 2 Emergency Communication Dilemmas Featured in the "SPARS Pandemic 2025-2028" Scenario}

Response Phase

- Engendering public trust and a sense of self-efficacy when a crisis is still evolving and critical health information is incomplete

- Responding to public and political pressure to share information about potential MCMs in the development pipeline even though information may be incomplete or proprietary

- Maintaining trust in government processes for ensuring the timely development of safe and effective vaccines when novel threats arise

- Harmonizing inconsistent messaging across health agencies

- Appropriately tailoring public health messages to address the concerns and culture of specific communities

- Responding to the power of graphic images of a child in distress: one story that is elevated to a population-level problem

- Responding to demand for an alternative antiviral drug not available in the United States

- Responding to misinformation or doubt about an MCM generated by a prominent public figure

- Overlooking communication platforms used by specific groups; quickly gaining fluency and effectively engaging the public using a new media platform

- Responding to public criticism about potential unequal access to MCMs like Kalocivir

- Maintaining public support after changing positions on MCM safety and efficacy

- Communicating the need for and reasoning behind the prioritization of scarce resources

- Publicizing MCM programs and availability to promote uptake and efficient distribution

- Providing real-time data on vaccine availability to align MCM supply with public demand

- Maintaining consistent messaging across electronic and non-electronic media and implementing a secondary communications plan if electronic media are not available

- Addressing multiple independent MCM concerns simultaneously

- Meeting the information needs of citizens who come from diverse cultural, social, and demographic backgrounds and who may have varying degrees of trust in health authorities

- Supporting the current MCM product in the face of opposition from a foreign regulatory agency 
- Responding to complex ethical issues that are beyond the United States government's control

- Responding to questions regarding safety and efficacy of drugs that have extended shelf lives

\section{Recovery Phase}

- Communicating with the public about trustworthy sources of data and options for legal recourse in a climate of mistrust

- Bringing a sense of resolution to a period of crisis while striking a balance between the need to affirm collective grief/loss and the need to move forward

- Institutionalizing communications lessons from the 2025-2028 SPARS pandemic

\section{Response Scenario Excerpt}

The following excerpt from the scenario takes place early on in the pandemic. One month previously the Food and Drug Administration (FDA) had issued an Emergency Use Authorization (EUA) for the antiviral Kalocivir. The drug had been evaluated as a therapeutic for other coronavirus-caused diseases and several million doses were maintained by the Strategic National Stockpile (SNS), which meant the drug could be deployed as necessary while production capacity was established to meet demand. The FDA and CDC provided information on the drug, but some differences in their messaging caused concern among certain groups including parents of young children. The specific communication dilemma this excerpt considers is how to confront the power of a single graphic image of a child in distress when one story is elevated to a population-level problem.

\section{"Going Viral"}

Reports of negative side effects associated with Kalocivir began gaining traction in February 2026. Despite the negative response, public health agencies continued to make forward progress until February 22, when a video of a 3-year-old boy in North Carolina projectile vomiting immediately after taking a dose of Kalocivir went viral. In the video clip, the boy swallows a pediatric dose of liquid Kalocivir, vomits profusely, chokes, and then faints in the pool of his own vomit while his mother shrieks in the background. 
This clip was widely shared across the United States with a variety of captions including \#AntiviralsDontWork, \#DontTake TheDrugs, and \#NaturalCuresAreBetterThanThis. The hashtags, in turn, provided a way for people sharing these views to find one another and band together on social media. They formed ZapQ and other online discussion groups, which allowed them to receive any messages from group members via smartphones and internet accessing technology (IAT) instantaneously as they were posted. Some members of these ZapQ groups even began to use full-sized $\left(12^{2} \times 12^{\prime \prime}\right)$ IAT screens on the backs of their jackets, coats, and backpacks to loop the vomiting video for all in their immediate vicinity to see.

The social media groundswell quickly overwhelmed the capacity of local, state, and federal agencies to respond, and compliance with public health and medical recommendations dropped considerably. The FDA and other government agencies quickly attempted to remind the public that correlation does not equate to causation, and that vomiting was not a known side effect of Kalocivir. This message, while scientifically accurate, lacked appropriate empathy and failed to assuage the public's mounting fears. As a result, it was largely ignored, and public concern continued to grow.

In the following weeks, officials from the FDA, CDC, and other government organizations attempted to promote positive, accurate information about Kalocivir on several traditional and social media platforms in order to quell public fear. This messaging, however, was less than optimal both in terms of timing and dissemination. While the government took several days to provide an emotionally appropriate message, the spread of the viral video on social media was exponentially faster. By the time the government responded, most people across the country had already seen the vomiting video and formed their own conclusions. Additionally, in their responses, governmental organizations were not able to effectively access all social media platforms. ZapQ groups, for example, had closed memberships and typically could only be accessed via invitations from group members.

Both of these issues prompted government organizations to improve the timing and impact of their social media responses. While most government agencies, including the CDC and HHS, 
had long-established offices that were directed to coordinate social media and other communication efforts, the protocols of individual agencies and different agency cultures led to delayed and sometimes uncoordinated messages.

Despite the many outreach efforts by various government officials and entities, the government was ultimately unable to develop a suitable replacement for the initial vomiting video. By early June 2026, the video had become the most shared Zap clip among junior high and high school students across the country who appreciated the shock factor of the video. As a result, the public was continually re-exposed to the anti-Kalocivir message for several months after the initial incident and subsequent responses.

\section{Food for Thought Questions:}

1. Why might communicating the science around MCM adverse effects alone not be enough to address people's fears and concerns about an MCM like Kalocivir? Why is it also important to communicate with compassion, concern, and empathy?

2. To what extent is having sufficiently skilled staff and organizational capacity to communicate via traditional media and social media platforms critical to influencing public debates and awareness about an MCM like Kalocivir?

3. What MCM communication challenges are likely to emerge among up-and-coming youth audiences who are avid consumers of interactive and visual forms of information?

\section{Recovery Scenario Excerpt}

The following excerpt from the scenario considers issues related with recovery, and how to communicate with the public about trustworthy sources of data and options for legal recourse in a climate of mistrust. At this point in the storyline, Corovax, the FDAapproved vaccine for SPARS, has been released for more than 9 months and the United States is solidly in the recovery phase of the pandemic. SPARS is now uncommon in the US and public focus has shifted from the disease to the potential side effects of SPARS treatments including the Corovax vaccine. 


\section{"Vaccine Injury"}

As time passed and more people across the United States were vaccinated, claims of adverse side effects began to emerge. Several parents claimed that their children were experiencing neurological symptoms similar to those seen among livestock exposed to the GMI vaccine. By May 2027, parental anxiety around this claim had intensified to the point of lawsuits. That month, a group of parents whose children developed mental retardation as a result of encephalitis in the wake of Corovax vaccination sued the federal government, demanding removal of the liability shield protecting the pharmaceutical companies responsible for developing and manufacturing Corovax.

The growing plaintiff cohort quickly withdrew their suit upon learning that the National Vaccine Injury Compensation Trust Fund (NVICTF) and an emergency appropriation of funds authorized by Congress under the PREP Act existed to provide financial reimbursement to those who were adversely affected by the Corovax vaccine in order to cover healthcare costs and other related expenses. Given the positive reaction to the federal government's response and the fact that the majority of US citizens willing to be vaccinated had already been immunized, the negative publicity surrounding adverse reactions had little effect on nationwide vaccination rates. The focus on adverse side effects, however, resulted in a considerable increase in the number of compensation claims filed, and many grew concerned about the long-term effects that Corovax could have on their health. This concern was particularly high among some African American parents who continued to question the government's motives regarding the Corovax vaccination campaign.

While the FDA, CDC, and other agencies were busy researching possible connections between Corovax and the reported neurological side effects, their efforts were continually undermined by epidemiological analyses produced by various non-governmental individuals and groups. The popular science blogger EpiGirl, for example, began posting interactive maps of the incidence of Corovax side effects in April 2027. To create the maps, EpiGirl collected anecdotes of adverse Corovax side effects using Facebook, Twitter, and YouTube and combined them with data downloaded 
from the HHS Vaccine Adverse Event Reporting System (VAERS), a national vaccine safety surveillance program maintained by the CDC and FDA. EpiGirl also encouraged those among her subscribers who were Apple product users to share health data with her via Apple's ResearchKit and HealthKit applications. EpiGirl's maps were consequently shared widely in social media circles and even included in local and national news reports.

The federal government became concerned about the validity of EpiGirl's anecdotal data and the widespread sharing of patient information via the internet. EpiGirl's data showed a significantly higher incidence rate of nearly every reported side effect; however, federal officials believed that this was largely due to duplicate entries resulting from compiling data from multiple sources. Additionally, EpiGirl's data did not seek to address the cause of the reported side effects, only the incidence rate. Publication of similar results from organizations such as Patients-Like-Me, a group closely associated with the natural medicine movement, further legitimized these independent reports. The government attempted to respond to these claims through formal press releases, but these were neither as visually appealing nor as interactive as EpiGirl's maps and were, therefore, largely ignored.

\section{Food for Thought Questions:}

1. How might advance development and testing of recovery messages that specifically address the topics of adverse side effects and the NVICTF help improve health authorities' ability to respond to public distress about medical issues emerging after an MCM campaign? What are some messages that would warrant such testing?

2. Despite the uncertain science about the link between Coravax and the reported neurological symptoms, why should health officials still communicate with compassion and genuine sympathy toward those in the vaccinated population who experience medical issues subsequent to being vaccinated?

3. Given growing interest in open data systems and the application of "crowd sourcing" to solve complex problems, how 
might public health officials take greater advantage of two-way communication with an interested public in the aftermath of the SPARS outbreak? For instance, how might input and analysis from members of the public help improve adverse event monitoring or assess the strengths and weaknesses of a specific MCM campaign?

\section{Crafting Scenarios: Lessons Learned}

Creating the scenario described above was a months-long process that involved many iterative steps. While the basic process of scenario development is both described above and detailed by others including Ogilvy and Schwartz (2004), the following are offered as lessons learned in order to assist in the development and design of scenarios in the future:

- Having a project team with different academic backgrounds (i.e., medicine, public health, and the social sciences) provided a solid foundation for developing the premise of the future in which the scenario would take place. Different perspectives, disagreements, and even lively debates were essential to developing a premise that was both realistic and meaningful. This process also provided forward momentum for the development of specific storylines.

- Storyboarding the timeline of events was important to maintaining coherency in the project. In the development of the SPARS scenario, storyboarding was not a one-time process but rather an ongoing exercise that occurred throughout scenario development.

- As storyboarding was occurring, it was essential to keep in mind the audiences for the project. In several cases, lessons specific audiences needed to walk away with were the starting point; the project team used these to work backward to make sure those lessons were fully incorporated into the storyline.

- A focus on small details, including using supporting illustrations like newspaper and social media headlines, was necessary to make the scenario as realistic as possible. This process 
of "sweating the small stuff" also provided a mechanism for the project team to check and recheck the accuracy of the overall product.

- Vetting the scenario with a group of subject matter experts was critical. In the SPARS scenario, this process helped identify dilemmas that were of particular relevance to specific target audiences as well as detect plot holes and inaccuracies that were necessary to fix in order for the storyline to be both believable and useful.

- Finally, developing facilitator guides along with the scenario was a way to increase the facility of the scenario as a teaching tool.

\section{Conclusion}

Effective communication about medical countermeasuresincluding drugs, devices, and biologics (e.g., vaccines)—is often critical in emergency situations. Such communication, however, does not just happen. It must be planned and prepared for. Prospective scenarios, like the SPARS scenario described in this paper, offer important opportunities for communication planning and preparation by enabling readers, both individually and in discussion with others, to rehearse responses to communication dilemmas; encouraging readers to envision what the next generation of best practices in MCM emergency communication may entail, given technological and social trends such as the growing influence of social media and increasing levels of social isolation; and prompting readers to consider and prepare for other future communication dilemma possibilities. In today's world of rapidlyevolving ICT, such preparation is especially crucial.

\section{ORCID}

Emily K. Brunson (1) https://orcid.org/oooo-0001-6321-1882

Hannah Chandler (1) https://orcid.org/0000-0003-0262-2295

Gigi Kwik Gronvall (1) https://orcid.org/oooo-0003-2514-146X 
Sanjana Ravi (1) https://orcid.org/oooo-0oo1-9769-6814

Monica Schoch-Spana (1) https://orcid.org/oooo-0oo2-8397-8367

Tara Kirk Sell (1) https://orcid.org/oooo-00o2-8342-476X

Matthew P. Shearer (i) https://orcid.org/oooo-0002-2031-2904

\section{References}

Allchin D. (2013). Problem- and case-based learning in science: An introduction to distinctions, values, and outcomes. CBE-Life Sciences Education, 12(3), 364-372. https://doi.org/10.1187/ cbe.12-11-0190

Belongia, E. A., Kieke, B., Lynfield, R., Davis, J. P., \& Besser, R. E. (2005). Demand for prophylaxis after bioterrorism-related anthrax cases. Emerging Infectious Diseases, 11(1), 42-47. https://doi.org/10.3201/eid1101.040272

Bishop, P., Hines, A., \& Collins, T. (2007). The current state of scenario development: An overview of techniques. Foresight, 9(1), 5-25. https://doi.org/10.1108/14636680710727516

Borjeson, L., Hojer, M., Dreborg, K. H., Ekvall, T., \& Finnveden, G. (2006). Scenario types and techniques: Towards a user's guide. Futures, 38, 723-739. https://doi.org/10.1016/j.futures. 2005.12.002

Carlsen, B., \& Glenton, C. (2016). The swine flu vaccine, public attitudes, and research interpretations: A systematic review of qualitative research. BMC Health Services Research 16(1), 203. https://doi.org/10.1186/s12913-016-1466-7

Centers for Disease Control and Prevention (CDC). (2018). Crisis and Emergency Risk Communication (CERC) manual. Retrieved from web archive at https://web.archive.org/ web/20190614141121/https://emergency.cdc.gov/cerc/ manual/index.asp

Charles-Smith L. E., Reynolds, T. L., Cameron, M. A., Conway, M., Lau, E. H. Y., Olsen, J. M., Pavlin, J. A., Shigematsu, M., Streichert, L. C., Suda, K. J., \& Corley, C. D. (2015). Using social media for actionable disease surveillance and outbreak management: A systematic literature review. PLOS ONE, 10(10): e0139701. https://doi.org/10.1371/journal.pone.0139701 
Courtney, B., \& Sadove, E. (2015). Medical countermeasures: Emergency preparedness and response roles and authorities. In: D. G. Adams, R. M. Cooper, M. J. Hahn, J. S. Kahan (Eds.), Food and Drug Law and Regulation (3rd ed., pp. 791-815). Food and Drug Law Institute.

Dart, R. C., Bronstein, A. C., Spyker, D. A., Cantilena, L. R., Seifert, S. A., Heard, S. E., \& Krenzelok, E. P. (2015). Poisoning in the United States: 2012 emergency medicine report of the National Poison Data System. Annals of Emergency Medicine, 65 (4), 416422. https://doi.org/10.1016/j.annemergmed.2014.11.001

Durigon, M., \& Kosatsky, T. (2012). Calls managed by the BC Drug and Poison Information Centre following the 2011 nuclear reactor incident at Fukushima, Japan. Canadian Pharmacy Journal, 145(6), 256-258. https://doi.org/10.3821/145.6.cpj256 Earthquake Engineering Research Institute (EERI). (2019). Developing earthquake scenarios. Retrieved from web archive at https://web.archive.org/web/20190416215029/http://www. nehrpscenario.org/

Edwards, I. R., \& Lindquist, M. (2011). Social media and networks in pharmacovigilance: Boon or bane? Drug Safety, 34(4), 26762271. https://doi.org/10.2165/11590720-000000000-00000

Epling, J. W., Morrow, C. W., Sutphen, S. M., \& Novick, L. F. (2003). Case-based teaching in preventive medicine: Rationale, development, and implementation. American Journal of Preventive Medicine, 24(4Suppl), 85-89. https://doi.org/10.1016/So749 3797(03)00028-X

European Centre for Disease Prevention and Control (ECDC). (2014). Handbook on simulation exercises in EU public health settings. Retrieved from web archive at https://web.archive.org/ web/20191107180459/https://ecdc.europa.eu/sites/portal/ files/documents/simulation-exercise-manual.pdf

Federal Emergency Management Agency (FEMA). (2019). Homeland Security Exercise and Evaluation Program (HSEEP). Retrieved from web archive at https://web.archive. org/web/20191004155411/https://www.fema.gov/hseep 
Fox, S. (2011). Health topics: 8o\% of internet users look for health information online. Pew Research Center's Internet \& American Life Project. Retrieved from web archive at https:// web.archive.org/web/20191107180641/https://www.issuelab. org/resources/9648/9648.pdf

Grajales, F. J., Sheps, S., Kendall, H., Novak-Lauscher, H., \& Eysenbach G. (2014). Social media: A review and tutorial of applications in medicine and health care. Journal of Medical Internet Research, 16(2), e13. https://doi.org/10.2196/jmir.2912 Guidry, J. P. D., Carlyle, K., Messner, M., \& Yin, J. (2015). On pins and needles: How vaccines are portrayed on Pinterest. Vaccine, 33, 5051-5056. https://doi.org/10.1016/j.vaccine.2015.08.064 Hamilton, D. S., \& Smith, B. T. (2006). Atlantic Storm. EMBO Reports, 7(1), 4-9. https://doi.org/10.1038/sj.embor.7400606 Hawn, C. (2009). Take two aspirin and tweet me in the morning: How Twitter, Facebook, and other social media are reshaping health care. Health Affairs, 28(2), 361-368. https://doi. org/10.1377/hlthaff.28.2.361

Henrich, N., \& Holmes, B. (2011). What the public was saying about the $\mathrm{H}_{1} \mathrm{~N}_{1}$ vaccine: Perceptions and issues discussed in on-line comments during the $2009 \mathrm{H}_{1} \mathrm{~N}_{1}$ pandemic. PLoS One, 6(4), e18479. https://doi.org/10.1371/journal.pone.0018479

Hinton, S., \& Hjorth, L. (2013). Understanding Social Media. Sage. Househ, M., Borycki, E., \& Kushniruk, A. (2014). Empowering patients through social media: The benefits and challenges. Health Informatics Journal, 2o(1), 50-58. https://doi. org/10.1177/1460458213476969

Inch, J., Watson, M. C., Anakwe-Umeh, S., on behalf of the Yellow Card Study Collaboration. (2012). Patient versus healthcare professional spontaneous adverse drug reaction reporting: A systematic review. Drug Safety, 35(10), 807-818. https://doi. org/10.1007/bfo3261977

Kata, A. (2012). Anti-vaccine activists, Web 2.0, and the postmodern paradigm - an overview of tactics and tropes used online by the anti-vaccination movement. Vaccine, 30, 3778-3789. https://doi.org/10.1016/j.vaccine.2011.11.112 
Keelan, J., Pavri-Garcia, V., Tomlinson, G., \& Wilson, K. (2007). YouTube as a source of information on immunization: A content analysis. Journal of the American Medical Association, 298(21), 2482-2484. https://doi.org/10.1001/jama.298.21.2482

Kreps, G. L., \& Neuhauser, L. (2010). New directions in eHealth communication: Opportunities and challenges. Patient Education and Counseling, 78, 329-336. https://doi. org/10.1016/j.pec.2010.01.013

Lin, L., Savoia, E., Agboola, F., \& Viswanath, K. (2014). What have we learned about communication inequalities during the $\mathrm{H}_{1} \mathrm{~N}_{1}$ pandemic: A systematic review of the literature. $B M C$ Public Health, 14(1), 484. https://doi.org/10.1186/1471-245814-484

Liu, B. F., Quinn, S. C., Egnoto, M., Freimuth, V., \& Boonchaisri, N. (2017). Public understanding of medical countermeasures. Health Security, 15(2), 194-206. https://doi.org/10.1089/ hs.2016.0074

Mahmoud, M., Liu, Y., Hartmann, H., Stewart, S., Wagener, T., Semmens, D., Stewart, R., Gypta, G., Dominguez, D., Dominguez, F., Hulse, D., Letcher, R., Rashleigh, B., Smith, C., Steer, R., Ticehurst, J., Twery, M., van Delden, H., Waldick, R., White, D., \& Winter, L. (2009). A formal framework for scenario development in support of environmental decisionmaking. Environmental Modeling \& Software, 24(7), 798-808. https://doi.org/10.1016/j.envsoft.2008.11.010

Matsuda, S., Kotonari, A., Tomizawa, S., Sone, M., Tanaka, R., Kuriki, H., \& Takahashi, Y. (2017). Analysis of patient narratives in diseases blogs on the internet: An exploratory study of social pharmacovigilance. JMIR Public Health and Surveillance, 3(1), e10. https://doi.org/10.2196/publichealth.6872

Miller, A. N., Sellnow, T., Neuberger, L., Todd, A., Freihaut, R., Noyes, J., Allen, T., Alexander, N., Vanderford, M., \& Gamhewage, G. (2017). A systematic review of literature on effectiveness of training in emergency risk communication. Journal of Health Communication, 22(7), 612-629. https://doi. org/10.1080/10810730.2017.1338802 
National Research Council (NRC). (2011). National Earthquake Resilience: Research, Implementation, and Outreach. The National Academies Press. https://doi.org/10.17226/13092

Ogilvy, J., \& Schwartz, P. (2004). Plotting Your Scenarios. Global Business Network. Retrieved from web archive at https://web. archive.org/web/20190803235747/http://www.meadowlark. co/plotting_your_scenarios.pdf

O’Toole, T., Mair, M., \& Inglesby, T. V. (2002). Shining Light on “Dark Winter." Clinical Infectious Diseases, 34(7), 972-983. https://doi.org/10.1086/339909

Poland, G. A., Jacobson, R. M., \& Ovsyannikova, I. G. (2009). Trends affecting the future of vaccine development and delivery: The role of demographics, regulatory science, the antivaccine movement, and vaccinomics. Vaccine, 27, 3240-3244. https://doi.org/10.1016/j.vaccine.2009.01.069

Preuss, J., \& Godfrey, J. (2006). Guidelines for Developing an Earthquake Scenario. Earthquake Engineering Research Institute (EERI). Retrieved from web archive at https://web. archive.org/web/20190812010728/https://mitigation.eeri.org/ files/Developing.a.Scenario.pdf

Quinn, S. C., Thomas, T., \& Kumar, S. (2008). The anthrax vaccine and research: Reactions from postal workers and public health officials. Biosecurity and Bioterrorism: Biodefense Strategy, Practice, and Science, 6(4), 321-333. https://doi.org/10.1089/ bsp.2007.0064

Rice, L., \& Sara, R. (2018). Updating the determinants of health model in the information age. Health Promotion International, 1-9. https://doi.org/10.1093/heapro/dayo64

Schoch-Spana, M., Brunson, E. K., Shearer, M. P., Ravi, S., Sell, T. K., Chandler, H., Gronvall, G. K. (2017). The SPARS Pandemic, 2025-2028: A Futuristic Scenario for Public Health Risk Communicators. Johns Hopkins Center for Health Security. Retrieved from web archive at https://web.archive. org/web/20190329230151/http://www.centerforhealth security.org/our-work/pubs_archive/pubs-pdfs/2017/ spars-pandemic-scenario.pdf 
Schoch-Spana, M., Gronvall, G. K., Brunson, E. K., Sell, T. K., Ravi, S., Shearer, M. P., \& Collins, H. (2016). How to Steward Medical Countermeasures and Public Trust in an Emergency-A Communication Casebook for FDA and Its Public Health Partners. Johns Hopkins Center for Health Security. Retrieved from web archive at https://web.archive. org/web/20190628210856/http://www.centerforhealth security.org/our-work/events/2016\%20FDA\%20MCM/FDA_ Casebook.pdf

Skryabina, E., Reedy, G., Amlôt, R., Jaye, P., \& Riley, P. (2017). What is the value of health emergency preparedness exercises? A scoping review study. International Journal of Disaster Risk Reduction, 21, 274-283. https://doi.org/10.1016/j. ijdrr.2016.12.010

Sloane, R., Osanlou, O., Lewis, D., Bollega, D., Maskell, S., \& Pirmohamed, M. (2015). Social media and pharmacovigilance: A review of the opportunities and challenges. British Journal of Clinical Pharmacology, 8o(4), 910-920. https://doi. org/10.1111/bcp.12717

Steelfisher, G., Blendon, R., Ross, L. J., Collins, B. C., Ben-Porath, E. N., Bekheit, M. M., \& Mailhot, J. R. (2011). Public response to an anthrax attack: Reactions to mass prophylaxis in a scenario involving inhalation anthrax from an unidentified source. Biosecurity and Bioterrorism: Biodefense Strategy, Practice, and Science, 9(3), 239-250. https://doi.org/10.1089/bsp.2011.0005

Tyrawski J., \& DeAndrea, D. C. (2015). Pharmaceutical companies and their drugs on social media: A content analysis of drug information on popular social media sites. Journal of Medical Internet Research, 17(6), e130. https://doi.org/10.2196/ jmir.4357

Ulmer, R. R., Sellnow, T. L., \& Seeger, M. W. (2017). Effective Crisis Communication: Moving from Crisis to Opportunity. SAGE Publications, Inc.

Uscher-Pines, L., Maurer, J., \& Harris, K. M. (2011). Racial and ethnic disparities in uptake and location of vaccination for 2009- $\mathrm{H}_{1} \mathrm{~N}_{1}$ and seasonal influenza. American Journal of Public Health, 101(7), 1252-1255. https://doi.org/10.2105/ ajph.2011.300133 
Varum, C. A., \& Melo, C. (2010). Directions in scenario planning literature-A review of the past decades. Futures, 42(4), 355369. https://doi.org/10.1016/j.futures.2009.11.021

Whitcomb, R. C., Ansari, A. J., Buzzell, J. J., McCurley, J. M., Miller, C. W., Smith, J. M., \& Evans, D. L. (2015). A public health perspective on the US response to the Fukushima Radiological Emergency. Health Physics, 108(3), 357-363. https://doi. org/10.1097/hp.0000000000000198

Wilkinson, A., \& Eidinow, E. (2008). Evolving practices in environmental scenarios: A new scenario typology. Environmental Research Letters, 3(4), 045017. https://doi.org/10.1088/17489326/3/4/045017

Witteman, H. O., \& Zikmund-Fisher, B. J. (2012). The defining characteristics of Web 2.0 and their potential influence in the online vaccination debate. Vaccine, 30, 3734-3740. https://doi. org/10.1016/j.vaccine.2011.12.039

Wolfe, R. M., Sharp, L. K., \& Lipsky, M. S. (2002). Content and design attributes of antivaccination web sites. Journal of the American Medical Association, 287(24), 3245-3248. https:// doi.org/10.1001/jama.287.24.3245

World Health Organization (WHO). (2018). A practical guide for developing and conducting simulation exercises to test and validate pandemic influenza preparedness plans. Retrieved from web archive at https://web.archive.org/web/20191107181633/ https://extranet.who.int/sph/sites/default/files/documentlibrary/document/9789241514507-eng.pdf 